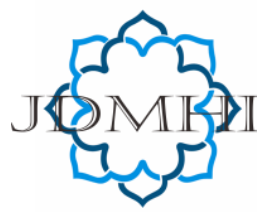

email: jdmhi@walisongo.ac.id

Journal of Digital Marketing and Halal Industry

ISSN: 2716-4810 (print) ISSN: 2716-4802 (online)

\title{
Digital Marketing During the Pandemic Period; A Study of Islamic Perspective
}

\section{Rahman E1 Junusi}

Fakultas Ekonomi dan Bisnis Islam, Universitas Islam Negeri Walisongo Semarang

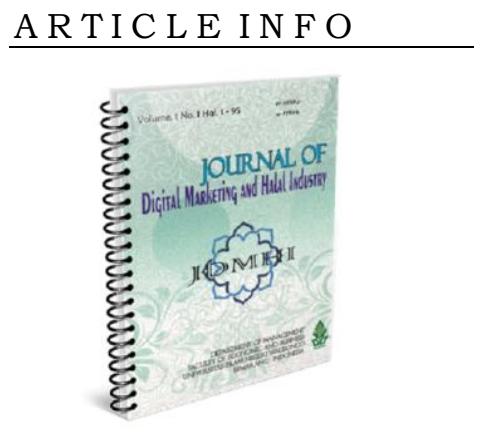

Article history:

Received 21 Mey 2020

Accepted 03 July 2020

Published 10 July 2020

Keywords:

Digital Marketing, Pandemic,

Technology and Information,

Consumers.
A B S T R A C T

The Covid 19 pandemic caused significant changes, especially those relating to marketing that led to digital usage. This article aims to determine the prospects and effects of digital marketing in the pandemic period and develop the concept of digital marketing from an Islamic perspective. The methodology of this article uses a descriptive qualitative approach by analyzing various literature on digital marketing. The results of this study found that advances in information technology played a role in the development of digital marketing, especially during the Covid-19 Pandemic. The characterization of digital marketing from an Islamic perspective will open new avenues for future research and will make researchers more theoretical. Sensitive to the ontological and epistemological assumptions underlying Islamic marketing research. This article contributes to the development of digital marketing from an Islamic perspective by introducing and characterizing potential new fields of Islamic marketing research. In the future, business people must follow technological advancements as digital marketing media to increase their marketing.

\section{@2020 Journal of Digital Marketing and Halal Industry}

Centers for Disease Control and Prevention, covid-19 anoints infectious and deadly virus. In the United States, the number of people infected and dying from coronavirus infections is increasing rapidly, so steps are needed to slow the spread of the pandemic virus globally and nationally (Fernandez \& Shaw, 2020).
Coronavirus is a new disease caused by covid19 currently affecting the joints of life throughout the world. Covid 19 pandemic is one of the global health crises and cannot be predicted in recent times. According to the 
Coronavirus transmission rates in the United States entered a new level on 28 April, 2020, because the total number of Covid-19 patients in this country has exceeded 1 million people. Deaths from Covid-19 in the US are also the most numerous in the world, which is more than 56 thousand people. In comparison, Indonesia ranks 36th in the list of countries with the highest number of positive corona cases in the world. The number of cases in the country also has the potential to overtake the number of infections in South Korea in the next few days if the addition of new patients continues to be consistently above 400 . Based on the latest data released by the Task Force for the Acceleration of Covid-19 Handling on 28 April, 2020, the total number of positive corona cases in Indonesia now reaches 9,511 patients.

Covid 19 pandemic has affected the joints of life. In the business world, a novel coronavirus in terms of social distance conditions forces companies around the world to ask millions of workers to work from home (Choudhury et al., 2020). At least 316 million people in 42 US states have been asked to stay at home, and later, businesses have been vulnerable to the transition to virtual workplaces or laying off employees (Kim, 2020). Many employees are quickly adjusting to digital transformation, Zoom's online video conferencing software reports a $78 \%$ profit growth, and a Google Meet report reports a $60 \%$ increase in user traffic, where people spend 2 billion minutes meeting online every day (Kim, 2020). Employees may not even want to return to the physical office after the pandemic has subsided. The manager estimates that some of the effects of covid 19 on the workplace may last long, where flexible working hours and digital meetings are expected to replace traditional corporate culture increasingly.

The company is experimenting with decentralized decision making and new software to make the new digital work culture effective and as productive as working in a physical office. Although businesses need to make this transition as effectively and as quickly as possible, several other consequences that are very important for business continuity are often overlooked namely the impact of covid 19 on consumer and market behaviour. Recently management practitioners and academics researched in response to covid 19, mainly focusing on the digital transformation of the workplace (Kim, 2020). According to the "Mere Urgency Effect" people tend to allocate most of their resources and time to problems (Zhu et al., 2018). According to a recent survey of 304 businesses, $42 \%$ are worried about revenue; however, most managers take an approach to wait and see rather than taking action to improve the situation (Kim, 2020). Managers may expect that sales will only recover as consumption increases after the pandemic passes. However, this pandemic has some impact on the culture of the place, the culture of consumers and may occur changing the structure of the market. Pandemics also influence digital transformation in terms of consumer behaviour and how businesses might adapt to digital marketing. Therefore the purpose of this article is how is the business opportunity with digital marketing during the pandemic and how is the perspective of the Islamic marketing perspective. Consumer insight during the pandemic shows that the market is turning to digital marketing. The rise of online transactions provides new opportunities for marketing success after covid-19. 


\section{Literature Review}

In the digital age, the transformation of communication channels is a challenge for all industries, but especially for the communications and marketing industry. As (Rangaswami \& Gupta, 2000) commented, "Marketing digitalization is a phase of change in the history of communication". (Jung, 2009) noted that changes in technology and consumer behaviour have always been the main drivers of change in marketing strategies. In today's changing digital environment "the speed, relevance and complexity of these elements become very important" (Jung, 2009). To be clear about understanding the definition of "digital marketing".

There is a lot of research on Digital Marketing or online marketing that comes up with many definitions of Digital Marketing. According to Kotler and Armstrong (2009), digital marketing is a form of direct marketing that connects consumers with sellers electronically using interactive technologies such as email, websites, online forums and newsgroups, interactive television, cellular communications and so on.

According to (Piñeiro-Otero \& MartínezRolán, 2016) digital marketing as a projection of conventional marketing, tools and strategies, on the Internet. The digital world and its application to marketing have driven the development of channels, formats and languages that lead to marketing tools and strategies. The Digital Marketing Institute (DMI) refers to digital marketing as "The use of digital technology to create integrated, targeted and measurable communications that help to obtain and retain customers while building deeper relationships with customers" (Royle \& Laing, 2014). "Digital marketing is a branch of traditional marketing and uses modern digital channels for product placement, e.g. music that can be downloaded, and especially for communicating with stakeholders, e.g. customers and investors about brands, products and business progress. " Both of these definitions are useful; the first because it emphasizes the importance of the strategic foundation for each marketing approach that is measurement and integration, and focuses on relationships and communication. The second definition functions for smart strategies and good communication; every use of digital marketing must be effective in promoting products or services (Royle \& Laing, 2014). So it can be concluded that digital marketing is marketing products or services using digital channels to reach consumers. The main objective is to promote the brand through various forms of digital media.

Digital marketing has become a new phenomenon that unites mass adjustment and distribution to achieve marketing goals. The convergence of technologies and device multiplication has led to the opening of the way we think about marketing on the Internet and has pushed the boundaries towards new concepts of digital marketing that are usercentred, more scalable, ubiquitous, and interactive. The development of digital marketing strategies offers a lot of potential for organizations. Digital marketing provides opportunities for businesses to gain economic value through collaboration with stakeholders, customers and employees (Purkayastha \& Sharma, 2016). Business leaders must incorporate digital marketing strategies into their business plans to reduce the likelihood of failure, grow their business, and be more profitable. Benefits of online marketing include (1) economic prices, (2) targeting 
various demographics at once, (3) providing products and services comfortably, and (4) allows customers to easily research products and services to speed up purchasing decisions (Durmaz \& Efendioglu, 2016).

Technological advances offer opportunities for business people to evaluate data and use the information to increase their productivity (Keegan \& Rowley, 2017). The practical use of various online tools by business people leads to new opportunities (Gaikwad \& Kate, 2016). The Internet is a trusted source by consumers before buying products and services. Businesses use the Internet as a marketing tool for financial success and to help foster communication with visibility and online sales channels and social media advertising to be a powerful way to reach various markets for business expansion (Banica et al., 2015). According to Bolat, Kooli, \& Wright, (2016), consumers use internet technology to increase numbers, which presents opportunities for businesses to reach out and connect with more people through websites and social media sites. (Smith, Smith, \& Shaw, (2017) state that $69 \%$ of consumers use social media to share information about products and services. However, succeeding with online marketing requires resources to create content and build quality followers.

Technology changes many aspects of business and market activities; technological advances have given birth to a method of transaction known as e-commerce (electronic commerce). The Internet has several attractions and advantages for consumers and organizations. The Internet is also the latest electronic media that support e-commerce (electronic commerce) and is experiencing rapid growth.

\section{Research Method}

The design/methodology/approach of this article is thought, or conceptual based on intellectualization and reflects the prospects and impacts of digital marketing. This study uses a critical approach to analytically review the literature on digital marketing and relate it to research results. Data analysis techniques used a descriptive

\section{Result and Discussion}

\section{Digital Marketing Prospects}

Based on Statista data, Indonesia is included in the ten countries with the largest internet users in the world. Indonesia is ranked fifth with 143.26 million internet users as of March 2019. This figure has a slight difference of 5.8 million with Brazil, which has 149.06 million internet users. As for the top-ranking obtained by China with a total of 829 internet users million. The second rank has quite a difference with China up to 269 million, namely India, with 560 million internet users. The United States (US) followed with as many as 292, 89 million internet users. As information, Statista said, there were 3.49 billion internet users worldwide. The distribution of internet users in East Asia is the largest, namely up to 923 million users. Statista 2019 data also shows that internet users in Indonesia in 2018 were 95.2 million, growing by $13.3 \%$ from 2017, which was 84 million users. In the following years, internet users in Indonesia will increase with an average growth of $10.2 \%$ in the 2018-2023 period. In 2019 the number of internet users in Indonesia was projected to grow by $12.6 \%$ compared to 2018, which is 107.2 million users. In 2023, the number of internet users in 
Indonesia is projected to reach 150 million users (https://databoks.katadata.co.id/).

The Global Web Index notes that Indonesia has the highest level of e-commerce users in the world. The report released by We Are Social states that $96 \%$ of internet users have searched for products or services to be purchased online. As for visits to online retail stores or related sites, $91 \%$ of total internet users have been visited. Internet users also pay for products or services online at $90 \%$. In sequence, they make online payments via cellphones and laptops or computers at 79\% and $29 \%$. The high level of usage is not directly proportional to the value of the ecommerce market in Indonesia. Because the market value in the country is still relatively low compared to the world average, on average each internet user in Indonesia spends the US \$ 89 dollars to shop on e-commerce, that figure is still below the average world internet user of US \$ 63 .

Based on data, online trade transactions in Indonesia grew rapidly; the annual number increased in 2014, the number of e-commerce transactions reached Rp. 25.1 trillion and will continue to increase in 2018, the number of ecommerce transactions will reach Rp. 144.1 trillion. And even according to a British research institute, Merchant Machine, released a list of ten countries with the fastest-growing e-commerce in the world. Indonesia leads the ranks of these countries with a growth of $78 \%$ in 2018. The number of internet users in Indonesia, which is more than 100 million users, is one of the forces driving e-commerce growth. The average money spent by Indonesians on online shopping sites is the US \$ 228 per person or around Rp. 3.19 million per person.
From the data, it can be concluded that in the future online marketing has very good prospects, so business people must adjust their market orientation strategies using the online marketing approach. According to Techopedia (2010), Online Marketing is a collection of powerful methodologies and tools used to market products and services via the Internet. According to Dolan, Conduit, Fahy, \& Goodman, (2017), online marketing (online marketing) is increasing content and changing the way individuals and organizations interact. Online marketing, commonly known as Internet marketing and digital marketing, can also be defined as the process of promoting a brand, product or service via the Internet (Tan et al., 2013). Digital marketing can provide benefits such as growth in potential, reduce expenses, provide elegant communication, better control, improve customer service and provide competitive advantages. Businesses need to ensure their processes are aligned with technological advancements. If it fails to recognize the potential benefits of online marketing, it can cause a loss of productivity, income, and communication (Cheng \& Liu, 2017). To maintain excellence, increase revenue and communication, businesses must plan to meet customer needs and ensure innovative technology strategies are implemented (Cheng \& Liu, 2017).

Based on the research results of the Institute for Economic and Community Research (LPEM), Faculty of Economics and Business, University of Indonesia revealed there are five reasons traders choose to sell online or ecommerce. In figure 1 , shows the highest reason sellers have more flexible business time, which is as much as $63 \%$. Besides, as many as $58.69 \%$ of sellers said there was an ease in running and managing a business online. Besides, the cheapness of selling online 
compared to opening an offline store was the third attraction that made sales choose to sell online, which was $49.52 \%$. The seller also felt that when selling online, the reach of buyers became wider, namely $48.69 \%$. Finally, as many as $44 \%$ said, selling online only requires a small capital.

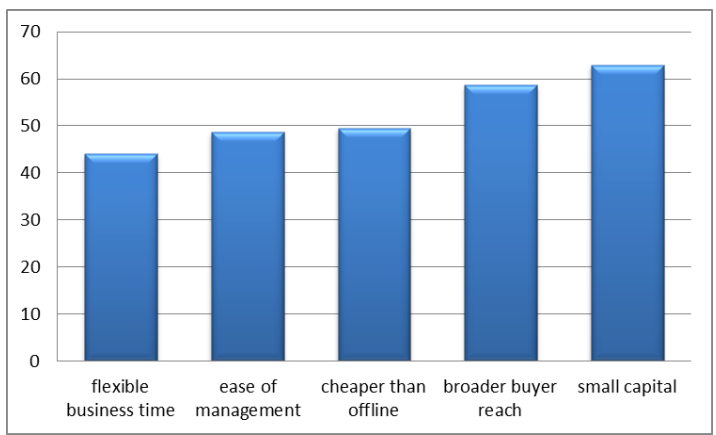

Source: (https://databoks.katadata.co.id/)

Figure 1. Reasons Traders Choose to Sell Online or E-Commerce

Concerning building customer loyalty, digital marketing is an effective way to attract consumers to be loyal. Marketers now have more touchpoints with consumers through digital channels than ever before. Digital marketing makes it possible to reach consumers in new ways. Also, with social media that has two-way communication in it, marketers can also see and understand more about its online consumers. However, online marketing has several disadvantages including Vulnerable to fraudulent activities (cybercrime), Vulnerable to technical errors, dependence on networks or on IT and Culture where there are still customers who prefer an offline store.

\section{Impact of COVID-19 on Consumer Behavior}

Pandemics, although considered an unlikely event for a long time before the covid-19 outbreak, have been identified as one of the main threats to business, according to a survey conducted in 2007 (P. W. Smith et al., 2007). Virtual meetings and project management techniques have increasingly been implemented even before the pandemic, and digital transformation has been relatively hassled free for many businesses. As such, the MOS business has successfully made the transition to online operations - however, the impact of the pandemic is not only limited to business operations.

Consumers living through a pandemic may change, and the changes can last long even after the pandemic has passed. According to a recent survey, $46 \%$ of respondents plan to reduce spending during a pandemic (Bhargav, 2020). Although the demand is increasing in certain categories, including food or household equipment, discretionary spending is expected to decrease because around $60 \%$ of respondents plan to cut spending on electronic goods or consumer vehicles. Managers may expect that sales will somehow recover when the situation subsides; whether and how many customers will return after a pandemic may depend on how well the business is adapting to a consumer culture that develops due to a pandemic (Bhargav, 2020).

According to a 2020 survey of 2,200 adults in the US, $37 \%$ of survey respondents considered switching to online shopping after covid 19 . Also, even late users, who had never used online shopping before, were asked to shop online because there was no alternative when taking shelter in place. Most of those who adopted late who did not like to shop online has entered the electronics market after covid 19. Among those surveyed, $11 \%$ Generation Z (Gen Z), 10\% Millennial, and 12\% 
Generation X (Gen X), and 5\% or Boomers have bought something online for the first time because of a pandemic. As a result, at least $66 \%$ of Gen Z, $68 \%$ of Millennial, and $73 \%$ of Gen X, and $68 \%$ of Boomers have adopted online shopping after a sharp increase in the number of online shoppers due to a pandemic (Kim, 2020).

Consumers adapt to online shopping. Shopping online offers greater flexibility in terms of time, location, and product variations. The existence of this pandemic can be encouraging consumers, who do not like the way shopping online until finally switching to shopping online (Muller \& Peres, 2019). Only $10 \%$ of consumers who adopt online shopping because of a pandemic, have already paid fees and experienced the convenience of online shopping and realize that a few days waiting for shipping might be in vain. (Rangaswami \& Gupta, 2000). Although late adopters tend to be more sceptical in evaluating new experiences, their online shopping experience tends to be positive, because it provides a relatively safe way to shop during a pandemic. As such, they tend to continue shopping online even after the pandemic has passed (Lin \& Lekhawipat, 2014).

\section{Digital Marketing In Islamic Perspectives}

Shariah marketing can be defined as a process and strategy (Wisdom) meeting the needs through Halal products and services (Tayyibat) with mutual agreement and welfare (Falah) from both parties namely buyers and sellers for the purpose of achieving material and spiritual well-being in the world here and at akhirat (Haque \& The, 2011) From its definition, the core aspects of Islamic marketing are strategy (wisdom), needs, halal (tayyibat), mutual agreement, and welfare (falah). Strategy (wisdom); the word closest to him in Islam is wisdom which is emphasized in adapting to certain situations. Islamic marketing can achieve long-term goals in this world and the hereafter by interacting with changing environments, situations and events to purify beliefs, views, morals, habits, habits, social, politics, culture, and economic life (Haque \& The, 2011). Joint agreement; based on the statement of the Quran and Sunnah, eg. AnNisa: 29, Ashura Shura: 38. In Islamic marketing, the collective agreement means that exchanges must be operated by the free will of buyers and sellers and free from undue pressure, fraud and fraud (Haque \& The, 2011). Needs; a person must consume according to his needs and marketing promotion activities must not deceive consumers and only for noble purposes by providing clear information for the benefit of the people. Halal (tayyibat); only goods that are safe, beneficial, and beneficial to consumers morally and ethically and do not conflict with what is prohibited by Islam are recognized as products (Haque \& The, 2011). Welfare (falah); business should not be solely directed by profit but also efforts to be upheld and improve human welfare (Alom and Haque, 2011). There are four characteristics of Islamic marketing; among them are spiritualistic, ethical, realistic, and humanistic. Spiritualism is the umbrella of all teaching in Islamic marketing (Arham, 2010). All business behaviour must be coherent with the teachings of the Koran and the Sunnah. Islamic marketers must be able to include the spirit of Islam in all aspects of marketing activities, from planning to after-sales services (Sula and Kartajaya, 2006).

Like other buying and selling transactions, in online marketing with e-commerce is also a buying and selling transaction, it's just that it's 
already modern. E-commerce uses technology in its transactions. If the sale and purchase transaction is carried out directly and tangible goods, this does not apply to e-commerce. In the e-commerce system, the sellers and buyers do not meet in person but meet in cyberspace with the goods to be traded usually displayed on the catalogue. This kind of transaction is actually quite profitable for buyers and sellers. A buyer can get the goods of his dreams just by using their smartphone, team, transactions, goods sent. On the seller's side, it is profitable, a seller simply opens an online store and waits for an order from the buyer, processes the product, and receives the proceeds from the sale of the item. However, in muamalah (Islamic trade law), the process of buying and selling transactions was regulated. General sale and purchase transactions regulated in Islam must involve a physical meeting between the seller and buyer, the goods to be transacted are also concrete, whereas e-commerce transactions do not apply that way.

In online marketing transactions through ecommerce does not mean that it does not cause problems for Muslims (given that 87\% of Indonesia's population are Muslims, then Muslims also have great potential to use ecommerce). Although e-commerce has spread throughout the world, there are still many Muslims who do not yet know what the status of online trading transactions they do in the perspective of Islamic law. For this reason, this article will discuss whether the prerequisites of Islamic trading laws have been fulfilled in the practice of e-commerce transactions. Therefore, for the successful implementation of Online Marketing with e-commerce, online businesses must know the strategic issues in Islamic marketing, namely, halal issues, legal issues, and branding issues, which have an impact on the successful implementation of Islamic marketing. It should also be noted that these three issues are also the main challenges facing Islamic marketing in the world today (Jan \& Wan, 2018)

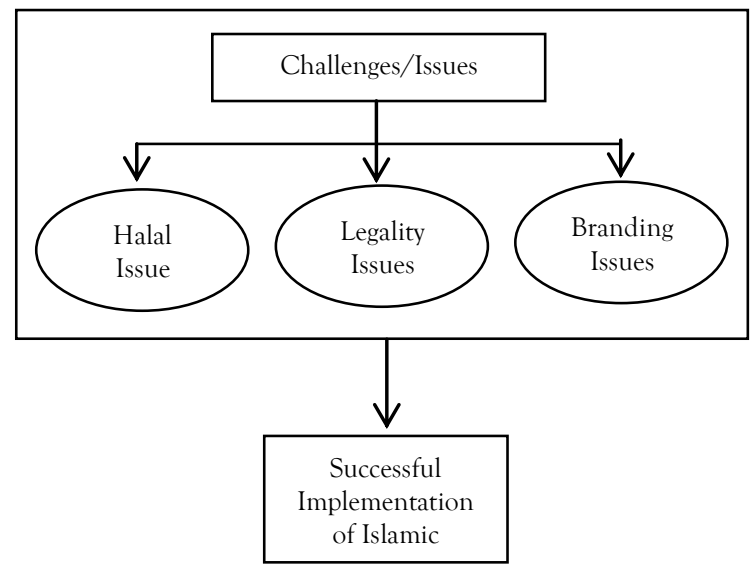

Figure 2. Implementation of Islamic Marketing in Online Transactions

First, the Branding Problem. Ahmed \& Jan, (2015); Abdullah et al., (2015) define Islamic branding as branding that is Islamic friendly and following Sharia guidelines. However, the definition of this Islamic brand can be further refined depending on the interpretation of branding. The definition of branding has been highly debated and is still being gone. That is why (Ahmed et al., 2015) proposed many new dimensions of Brand Islam. Apart from the above, halal matters will always be like a mystery (Wilson, 2012). This is because, in the end, Allah SWT determines whatever is considered halal or not halal.

Second, the Halal Problem. In online marketing, any product offered by the company to consumers, especially Muslim Consumers, must be fully halal or permitted in Islam. Therefore, all processes, inputs, and 
all involved from creation to product delivery must be environmentally friendly. Islam strictly forbids, causing damage to the Islamic environment or anything created by Allah (SWT). It must also be free from any elements that break the law, which is prohibited in Islam (Arham, 2010). Jan \& Wan, (2018) suggested that products reduced as Makrooh or Mushtabeh would be very difficult to sell to Muslim consumers. The same idea applies to organizations that produce products that contain some unlawful elements that are prohibited in Sharia.

Muslim target markets are extra sensitive and easily influenced when they see products, processes, organizations or elements in certain products that can be categorized as Haram or un-Islamic (Wilson, 2012). Many organizations produce Islamic products that are permitted in Islamic law, but their business also deals with the production of goods that are not acceptable in Islam. Therefore according to Islamic law, it does not matter if they produce Islamic products that are permitted to enter Sharia, as long as they produce products that are not Islamic, their business as a whole is considered illegal (Jan \& Wan, 2018). Therefore, food marketers and other producers need to understand the true meaning of Halal (Wilson, 2012). The point for all marketing practices whether Islamic or conventional, is to deal honestly and morally (Ahmed \& Jan, 2015)), which is consistent with Islamic ethical guidelines that design Islamic ethical marketing frameworks. Marketers must see these rules and regulations as important in marketing (both conventional and Islamic) and Islamic ethical marketing practices. When the principles of Islamic ethics within the Islamic framework are integrated into modern law, an environment of ethical behavior will likely develop.
Especially because human nature is relatively the same, these ethical principles adopted by Muslims globally will remain valid for all beliefs. Therefore, adoption and use of ethical Islamic business practices will help multinational companies to take advantage of the large Muslim market. Operating a business from an Islamic perspective on those markets is a guarantee of success. Besides, following these principles also helps in the creation of a global ethical marketing model for all Jan \& Wan multinational companies, (2018).

Third, Legality (Absorbing Islamic teachings in Modern Law). Theoretically, some contemporary marketing practices are considered legitimate and valid according to Islamic ethical principles (Arham, 2010). Therefore, if marketers can take this opportunity, they can do so successfully combining Islamic principles in contemporary marketing practices. The Indonesian government, for example, follows conventional marketing practices but has strict rules and regulations on market monopolies and food quality from both a hygienic and Islamic perspective (Ahmed, 2015; Wilson, 2012).

The point of marketing practices whether Islamic or conventional is to deal with honest and moral ways (Flint \& Maignan, 2015), which is consistent with Islamic ethical guidelines that design Islamic ethical marketing frameworks (Sacharow, 1995; Leaman, 2005). Marketers must see these rules and regulations as important in marketing (both conventional and Islamic) and Islamic ethical marketing practices. When the principles of Islamic ethics within the Islamic framework are integrated into modern law, an environment of ethical behavior will likely develop. 
In addition to the three issues above, businesses run through online marketing have characteristics based on Sharia law, including (1) Operations in online do not contain usury (interest): "Allah destroys usury and fertilizes alms. And Allah does not like everyone who remains in disbelief, and always sins "(Al Baqarah: 276), (2) Operations in online do not contain Maisir (gambling):" They ask you about wine and gambling. Say: "There is a great $\sin$ in it, and there are benefits to it, for humans; but that $\sin$ is greater than the profit." They ask you how much they have to spend: Say: "What is beyond your needs." Thus Allah explains to you His signs: So that you can be silent "(Al Baqarah: 219), (3) Activities that involve making and / or selling illicit products (prohibited). The Prophet (PBUH) said, "Allah has set certain obligations for you, so do not ignore them; He has set certain limits, so don't go beyond them; He has forbidden certain things, so don't do it; and He has kept quiet about other things out of mercy to you and not because of forgetfulness, so do not ask about them ". (Reported by aIDarqutni and classified as hasan (good) by alNawawi.), (4) Operations containing the element of Gharar (uncertainty). Ibn Majah on the authority of Abu Hurairah (r.a) that "The Prophet (PBUH) prohibited the sale of gravel and the sale of Gharar".

Yusof Qardawi mentioned in his book The Lawful and Forbidden in Islam, "Islam does not prohibit any trade except that involves injustice, deceiving, making exorbitant profits, or promoting something unlawful" (Qardawi, 1960). The objectives of Islamic Business will double; maximizing profits and also welfare or maximizing Falah. Islamic business will consider the benefits of the whole community as well as other priorities in Islamic countries (Sarker, 2001).

Online Marketing does have a place in an Islamic perspective, but Shariah requirements must be obeyed and obeyed. This is to ensure that objectives regarding online business, which are various; falah and profit maximization can be achieved. By achieving these goals Muslims can succeed in business and also in the hereafter. Falah maximization can be achieved by complying with Sharia and the four main prohibitions outlined are the prohibition of Riba, Maisir, and Gharar and the sale of prohibited products. On the other hand, maximizing profits from online marketing can be achieved by differentiating products, quality and services offered to customers through the marketing mix and online networking.

\section{Conclusion}

Digital marketing has grown rapidly. Advances in information technology have changed many aspects of business, marketing activities, and gave birth to online transaction methods. During the covid pandemic 19, businesses have transformed transactions through digital marketing. At the time of the pandemic has accelerated the growth of digital marketing which has an impact on changing consumer behaviour towards online transactions. However, the development of digital marketing must obey and be guided by Islamic values. Therefore the conceptual model of developing digital marketing in an Islamic perspective can be explained in the following figure: 
Figure 3. Developing Digital Marketing in an Islamic Perspective

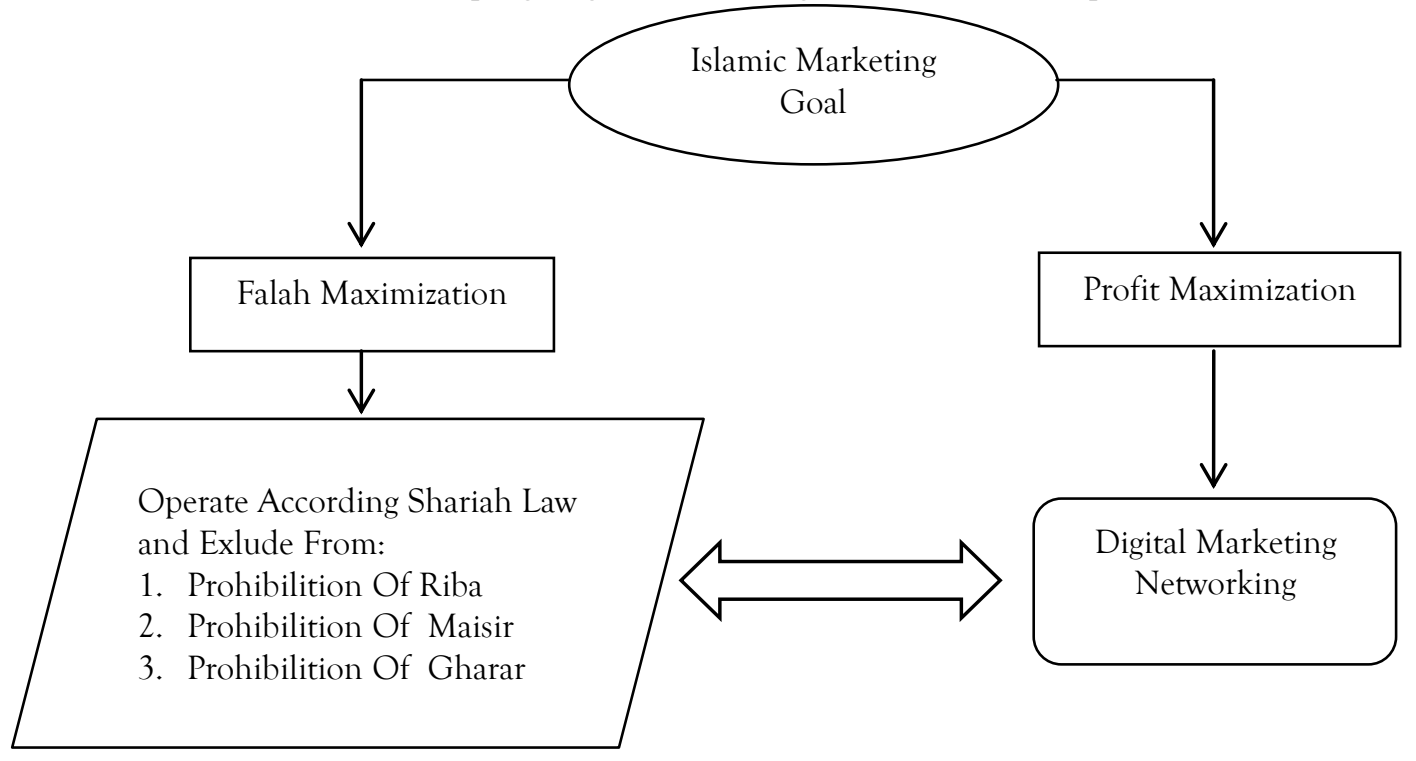

\section{Recommendation}

The characterization of digital marketing from an Islamic perspective will open new avenues for future research and will make researchers more theoretically sensitive to the ontological and epistemological assumptions underlying Islamic marketing research. But the limitations of the study of digital marketing in an Islamic context are very rare. Practical implications, practitioners must realize that technological advances have given birth to a transaction method known as digital marketing so that it is an opportunity for business people to evaluate data and use digital marketing to improve their marketing. In theory, practitioners and academics will find a better platform for developing digital marketing in an Islamic perspective.

\section{References}

Abdullah, J. Bin, Hamali, J. H., \& Abdullah, F. (2015). Success Strategies in Islamic Marketing Mix. Journal of Islamic Marketing, 6(3), 480-499. https://doi.org/10.33736/ijbs.581.2015

Ahmed, M., \& Jan, M. T. (2015). Applying the factor analytical approach towards Aaker's brand personality model from an Islamic perspective. Malaysian Management Review, 50(1), 49-63.

Ahmed, M., Tahir, M., Ahmed, M., Tahir, M., Ahmad, M. F., Kashif, M., Run, E. C. De, Rehman, M. A., Ting, H., Ahmad, A. N., Yang, T. A., Nadiah, W., \& Abdullah, W. (2015). An extension of Aaker's brand personality model from 
Islamic perspective: a conceptual study. Journal of Islamic Marketing, 6(3), 388405.

Ahmed, S. (2015). the Effects of Marketing Mix on Consumer Satisfaction: a Literature Review From Islamic Perspectives. Turkish Journal of Islamic Economics, 2(1), 17-17. https://doi.org/10.15238/tujise.2015.2. $1.17-30$

Arham, M. (2010). Islamic perspectives on marketing. Journal of Islamic Marketing, $1(2)$, 149-164. https://doi.org/10.1108/175908310110 55888

Banica, L., Brinzea, V., \& Radulescu, M. (2015). Analyzing Social Networks From the Perspective of Marketing Decisions. Scientific Bulletin: Economic Sciences, 14(3), 37-50

Bhargav, S. (2020). Survey: Portuguese consumer sentiment during the coronavirus crisis. Mckinsey and Co., April 5, 2020. [Online]

Https://Www.Mckinsey.Com/Businessf unctions/Marketing-and-Sales/OurInsights/Survey-Us-Consumer-Sentimentduring-Thecoronavirus-Crisis. https://www.mckinsey.com/businessfunctions/marketing-and-sales/ourinsights/survey-portuguese-consumersentiment-during-the-coronavirus-crisis

Bolat, E., Kooli, K., \& Wright, L. T. (2016). Businesses and mobile social media capability. Journal of Business and Industrial Marketing, 31(8), 971-981. https://doi.org/10.1108/JBIM-10-2016270
Cheng, J. H., \& Liu, S. F. (2017). A study of innovative product marketing strategies for technological SMEs. Journal of Interdisciplinary Mathematics, 20(1), 319337.

https://doi.org/10.1080/09720502.201 6.1258837

Choudhury, P., Koo, W. W., \& Li, X. (2020). Working (From Home) During a Crisis: Online Social Contributions by Workers During the Coronavirus Shock Working ( From Home ) During a Crisis : Online Social Contributions by Workers During the Coronavirus Shock (Working Paper 20096).

Dolan, R., Conduit, J., Fahy, J., \& Goodman, S. (2017). Social media: communication strategies, engagement and future research directions. International Journal of Wine Business Research, 29(1), 2-19. https://doi.org/10.1108/IJWBR-042016-0013

Durmaz, Y., \& Efendioglu, I. H. (2016). Travel from Traditional Marketing to Digital Marketing. Global Journal of Management and Business Research: E Marketing, $\quad 6(11), \quad 173$. https://doi.org/10.23956/ijermt.v6i11.6 0

Fernandez, A. A., \& Shaw, G. P. (2020). Academic Leadership in a Time of Crisis: The Coronavirus and COVID-19. Journal of Leadership Studies. https://doi.org/10.1002/jls.21684

Gaikwad, M. J., \& Kate, P. H. (2016). EMarketing: a Modern Approach of Business at the Door of Consumer. International Journal of Research in Commerce $\mathcal{E}$ Management, 7(9), 56-62. 
Haque, M. M. A. and M. S., \& The. (2011). Social marketing: an Islamic perspective. World Journal of Social Sciences, 1(3), 7181. https://doi.org/10.1108/JIMA-122016-0105

Jan, M. T., \& Wan, H. L. (2018). Will Islamic Marketing Survive in Today's World? ERA Journal ID, 16(2), 9-17.

Jung, J. (2009). Strategic Management in the Media: Theory to Practice, by Lucy Küng - International Journal on Media Management, 11(1), 46-47. https://doi.org/10.1080/142412708026 34120

Keegan, B. J., \& Rowley, J. (2017). Management Decision Evaluation and decision making in social media marketing Article information. Management Decision, 55(1), 15-31. https://doi.org/10.1108/MD-10-20150450

Kim, R. Y. (2020). The Impact of COVID-19 on Consumers: Preparing for Digital Sales. IEEE Engineering Management Review, 8581(c), 1-1. https://doi.org/10.1109/emr.2020.2990 115

Lin, C., \& Lekhawipat, W. (2014). Factors affecting online repurchase intention. Industrial Management and Data Systems, 114(4),

597-611. https://doi.org/10.1108/IMDS-10-20130432

Muller, E., \& Peres, R. (2019). The effect of social networks structure on innovation performance: A review and directions for research. International Journal of Research in Marketing, 36(1), 3-19. https://doi.org/10.1016/j.ijresmar.2018
.05 .003

Piñeiro-Otero, T., \& Martínez-Rolán, X. (2016). Understanding Digital Marketing-Basics and Actions. In MBA Theory and Application of Business and Management Principles (pp. 37-74). Springer International. https://doi.org/10.1007/978-3-31928281-7_2

Purkayastha, A., \& Sharma, S. (2016). Gaining competitive advantage through the right business model: analysis based on case studies. Journal of Strategy and Management, 9(2), 138-155.

Rangaswami, A., \& Gupta, S. (2000). Innovation Adoption and Diffusion in the Digital Environments: Some Research Opportunities. In In Vijay Mahajan, Eitan Muller, and Yoram Wind (Eds.), New Product Diffusion Models (pp. 85-101).

Springer. https://doi.org/10.1080/135272609027 57506

Royle, J., \& Laing, A. (2014). The digital marketing skills gap: Developing a Digital Marketer Model for the communication industries. International Journal of Information Management, 34(2), 65-73.

https://doi.org/10.1016/j.ijinfomgt.201 3.11 .008

Sarker, A. A. (2001). Islamic Business Contracts, Agency Problem and the Theory of the Islamic Firm. International Journal of Islamic Financial Services, 1(2), 01-15. https://doi.org/10.1093/jis/12.3.329

Smith, C., Smith, J. B., \& Shaw, E. (2017). Journal of Business Venturing 
Embracing digital networks: Entrepreneurs 'social capital online. Journal of Business Venturing, 32(1), 1834.

https://doi.org/10.1016/j.jbusvent.2016 .10 .003

Smith, P. W., Hansen, K., Spanbauer, L., \& Shell, D. F. (2007). Pandemic influenza preparedness: A survey of businesses. American Journal of Infection Control, 35(7), 484-485. https://doi.org/10.1016/j.ajic.2006.11.0 08

Tan, K. S., Chong, S. C., \& Lin, B. (2013). Intention to use internet marketing: A comparative study between Malaysians and South Koreans. Kybernetes, 42(6), 888-905. https://doi.org/10.1108/K-122012-0122

Wilson, J. A. j. (2012). The new wave of transformational Islamic marketing: Reflections and definitions. Journal of Islamic Marketing, 3(1), 5-11. https://doi.org/10.1108/175908312112 25436

Zhu, M., Yang, Y., \& Hsee, C. K. (2018). The Mere Urgency Effect. Journal of Consumer Research, 45, 673-690. https://doi.org/10.1093/jcr/ucy008 